Reconstructing Ashkenaz 
Stanford Series in Jewish History and Gulture edite д в у Aron Rodrigue and Steven J. Zipperstein 


\section{Reconstructing Ashkenaz}

\section{The Human Face of \\ Franco-German Jewry, I000-I250}

David Malkiel

STANFORD UNIVERSITY PRESS 
Stanford University Press

Stanford, California

(C) 2009 by the Board of Trustees of the Leland Stanford Junior University. All rights reserved.

Publication assistance for this book was provided by the Taube Center for Jewish Studies of Stanford University.

No part of this book may be reproduced or transmitted in any form or by any means, electronic or mechanical, including photocopying and recording, or in any information storage or retrieval system without the prior written permission of Stanford University Press.

Printed in the United States of America on acid-free, archivalquality paper

Library of Congress Cataloging-in-Publication Data

Malkiel, David Joshua.

Reconstructing Ashkenaz : the human face of Franco-German Jewry, I000-I250 / David Malkiel.

p. cm. - (Stanford series in Jewish history and culture)

Includes bibliographical references and index.

ISBN 978-0-8047-5950-2 (cloth : alk. paper)

I. Judaism-Relations-Christianity. 2. Christianity and other religions-Judaism. 3. Crusades. 4. Ashkenazim-Europe, Western-History-To I500. 5. Sephardim-History. I. Title. II. Series.

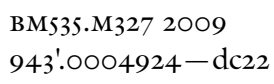

Typeset by Bruce Lundquist in I0.5/14 Galliard. 
To My Wife 
